\title{
IBN 'ARABI'S INFLUENCE ON OTTOMAN SUFISM IN ÜFTADE’S VIEWS
}

\author{
AHMAD MUNJI AND SEMIH ÇEYHAN* \\ Marmara Üniversitesi, Istanbul Turkey
}

\section{Abstract}

As a great figure, Ibn 'Arabi's thoughts greatly influenced the Sufis who came after him. In fact, some researchers in the field of Sufism say that there are new characteristics that have emerged in the history of Sufism after Ibn 'Arabi, namely philosophical Sufism. The same influence can also be found in the tradition of Sufism thought on Ottoman, one of them is Üftade. In his work entitled Vâkıât, Üftade mentions Ibn 'Arabi's name more than 40 times in various topics of discussion. For example, Üftade claimed that he had met Ibn 'Arabi several times in his dreams, Ibn 'Arabi's level of wilayah and so on. By using the content analysis method, this paper tried to see how the Üftade's view of Ibn 'Arabi's thoughts actually was, his works and his level of wilayyah among other Sufi figures.

Sebagai tokoh besar, pemikiran Ibn 'Arabi sangat memengaruhi para Sufi yang datang setelahnya. Babkan, beberapa peneliti di bidang tasawuf mengatakan bahwa ada karakteristik baru yang telah muncul dalam sejarah tasawuf setelah Ibn 'Arabi, yaitu tasawuf filosofis. Pengarub yang sama juga dapat ditemukan dalam tradisi pemikiran tasawuf pada Ottoman, salah satunya adalah Üftade. Dalam karyanya yang berjudul Vâkıât, Üftade menyebutkan nama Ibn 'Arabi lebih dari 40 kali dalam berbagai topik diskusi. Misalnya, Üftade mengklaim bahwa dia telah bertemu Ibn 'Arabi beberapa kali dalam mimpinya, tingkat wilāyah Ibn 'Arabi

\footnotetext{
* Corresponding author: Semih Çeyhan, Eğitim Mahallesi, Fahrettin Kerim Gökay Cd., 34722 Kadıköy/İstanbul, Turkey. E-mail: semihceyhan@yahoo.com.

ISSN 0852-7172 (p) 2461-064X (e) 
dan sebagainya. Dengan menggunakan metode content analysis, makalah ini melihat bagaimana sebenarnya pandangan Üftade tentang pemikiran Ibn 'Arabi, karya-karyanya dan tingkat wilāyahnya di antara tokoh-tokoh Sufi lainnya.

Keywords: Ibn 'Arabi; Ottoman Sufism; Sufi; tariqa; Üftade’s view.

\section{Introduction}

Discussing Ibn 'Arabi's influences on Ottoman era is not something new. Because, on the trip covered by Ibn 'Arabi from Cordova to Islamic nations in Africa and Asia, Ibn 'Arabi halted twice at Konya, the capital city of Seljuk empire. Even, when Ibn 'Arabi was in Konya, he married with a woman whose son is Ibn 'Arabi's student named Sadreddin Konavi (Kilic 2013, 493). Thereby, Ibn 'Arabi's influence was very great and loved by his students in Konya and generations in the city.

Sadreddin Ebu'l Meal-i Ishak Muhammed Yusuf Ali el-Konevi was the first religious scholar influenced by the ideas of Ibn 'Arabi. Some sources argue that the widowed mother of Sadreddin Konevi was married to Ibn 'Arabi. However, this seems to be an unjustified argument in terms of a historical point of view. According to Hudaverdi Adam, there are at least two aspects of Ibn 'Arabi's influence which can be seen in el-Konavi; the intellectual influence, and the social and human influence. Intellectually, of course, Sadruddin Konawi's thoughts were greatly influenced by Ibn 'Arabi, because he was a student of Ibn 'Arabi. While social and human influences are due to the fact that Ibn 'Arabi was not only the teacher for Sadruddin Konavi. He was a father who cared a lot for Konavi from the beginning he started the Sufi path (Hudaverdi 2005, 153)

Sadruddin Konavi certainly was not the only person influenced by the ideas of Ibn 'Arabi. After the departure of Ibn 'Arabi from Konya, he appointed Sadruddin Konevi to become his 
khalifah (deputy) in continuing what he was fighting for in the Anadolu region. The effort of Sadruddin Konavi to continue the preaching of Ibn 'Arabi gained its success. It was evidenced by the acceptance of the ideas of Ibn 'Arabi by scholars at that time and those who came after him. There are many names of great figures in the Ottoman empire that can be grouped into followers of Ibn 'Arabi. Some of them wrote something directly related to the works of Ibn 'Arabi. There were certainly also shaikhs who never wrote anything, but followed the Akbarian doctrine.

The names that can be grouped into Ibn 'Arabi's followers and successors are; Daud al-Qaysari (d. 751/1350), Molla Fanari (d. 834/1430), Muhammad Quṭb al-Din al-Izniki (d. 855/ 1450), Yazicizade Muhammad Efendi (d. 855/1451), Ismail Hakki al-Bursawi (d. 1137/1724), Muhammad Muhyidin Üftade (d. 968/1580), Ahmed Avni Konuk (d. 1938) and many others.

Üftade was one among the most influential figures on Sufi in the beginning of Ottoman empire. He was well-known as an important person in founding Jalwetiyah tariqa ${ }^{2}$. On the beginning, Üftade was a follower of Bairamiyah tariqa and became khalifah of his teacher Hizir Dede (918/1512). Yet, his spiritual path was followed by his student Aziz Mahmud Hudayı (1038/1628)³. In

\footnotetext{
${ }^{2}$ Celvetiyah is a tariqa (Sufi order) founded by Aziz Mahmud Hudayı who was a student of the Üftade. Basically, this tariqa is a branch of the Bairamiyah which was founded by Haji Bayram Wali. Aziz Mahmud Hudayı obtained the genealogy of the Bairamiyah Order from his teacher, Üftade, Hizır Dede, Akbaylık Sultan and Haci Bayram Wali. On the other side, tariqa Celvetiyah also has a close relationship with the Naqshabandiyah tradition. That is why there are some teachings of the Naqshabandiyah Order which are also used in the Celvetiyah order, such as the "nazar berkadem", "halvet der-encümen" and "haf zikir" (Yilmaz 1982, 42).

${ }^{3}$ His original name was Mahmud. His students then called him with Hudayı and Aziz. Hudayı was born in Sereflikoçhisar in 1541. His childhood was spent at Sivrihisar by starting to study basic Islamic sciences. Then Hudayı was sent to Istanbul and entered a madrasa in the district of Kücükayasofya. After completing his education at the madrasa, Hudayı began to start the spiritual path under Shaikh Nazir Zade. When Nazir Zade was appointed to teach at the madrasa at the Salimiye mosque in Edirne, until be a judge in Sham and Egypt, Hudayı always accompanied him every time.
} 
Hudayı's hand, Üftade's spiritual path transformed to an independent tariqa and is called later as Celvetiyah tariqa.

Üftade's influences in Sufism tradition at Ottoman empire are numerous. One of them can be seen from the his student named Aziz Mahmud Hudayı, that would be the influential figure in Ottoman and work written from his dialog with Aziz Mahmud Hudayı entitled Vâkiât. Vâkıât is not only Üftade work. More than that, some say that he has another work in prose and poetry version entitled Divan, and a speech collection "Hutbe Mecmuesi". Unfortunately, his third work was not found physically and is questionable whether it really exists or only a chit-chat story, meanwhile his work "Divan" has been translated into France and English.

In Vâkıât, Üftade mentioned Ibn 'Arabi's name repeatedly and it can be found in every volume of the book. Ibn 'Arabi's name is mentioned more than 40 times in many texts. For instance, when Üftade told about his meeting with Ibn 'Arabi, his discussion about maqāmat in sufism, his response on Ibn 'Arabi's idea which is followed by his critics, his narrative on the history of Ibn 'Arabi grave location. Mentioning Ibn 'Arabi in Vâkıât brings up two possibilities. First, Üftade really admires Ibn 'Arabi, or second, he disagrees with and criticizes Ibn 'Arabi's opinion.

First possibility is more accepted since one of his comments emphasizes that "Ibn 'Arabi is one of Sufi abl al-fana', he had been in quṭb al-aqtāb level” (Hudayı, n.d., 66A). The Üftade's statement is most likely an expression of his admiration to Ibn 'Arabi. Although he was not living in one period with Ibn 'Arabi, his meeting with him in the dream made him like a student of Ibn 'Arabi.

After returning from Egypt, Hudayı moved to the Bursa and met with the Üftade. Under the supervision of Üftade, Hudayı continued his spiritual education for three years until he was appointed to be a khalifah and was given the task of returning to his hometown of Sivrihisar (Yilmaz 1982, 20). 
Though Üftade didnot only mention Ibn 'Arabi's name in Vâkıât, it seems that the prominent references from Vâkıât writing is Ibn 'Arabi's works i.e., Fusūs and Futuhăt, and also from the result of his meeting with Ibn 'Arabi in a dream. Another Sufi figure mentioned a lot in his book is Maulana Jalāluddīn al-Rūmi, there are 20 times approximately.

Through this paper, the writer attempts to read the works of Üftade which are still considered manuscript. In order to know his view on Ibn 'Arabi's thoughts, works, maqāmat, and biography obtained about the location of his grave on his vacated works. While using content analysis method, the writer groups Üftade's discussion about Ibn 'Arabi in several discussion themes.

\section{Üftade: a Sufi from Ottoman}

His inborn name was Mehmed (Muhammad) and his nickname was Muhyiddin. However, on his voyage, he was wellknown as Üftade (fallen down). Continually, to easily mention his name, the author uses the name Üftade in this paper. There are different sources in informing the year he was born. Most sources revealed that Üftade was born in 895 A.H. (1490 A.D), one of them was Paul Ballanfat. Otherwise, there is a more authoritative source written by Aziz Mahmud Hudayı as his student, that Üftade was born in 900 A.H./1495 A.D, five years earlier than many quoted statements. His father was from Manyas, and moved to Bursa as the capital city of Ottoman in its early age. His father's occupation was silk weaver. Later, the young Üftade helped his father's profession (Azamat 2012, 282).

Little Üftade studied under his teacher/shaikh Muk'ad Hizir Dede (918 A.H/1512 A.D), a spiritual guide (murshid) of Bairamiyyah tariqa located in Bursa. Until his teacher passed away in 918/1512, he faithfully studied only with a teacher for approximately 8 years. The young Üftade recognized that he had a melodious voice as he was pointed by the Ottoman government 
to become muadhin in a Bursa grand mosque "ulu cami", the biggest mosque in Bursa. Purportedly, his melodious voice could make its audiences cry (Azamat 2012)

As a muadhin, Üftade could gain a good salary from the government. Yet it did not make his feeling convenient. Until in one night, he dreamed that he heard voice admonishing him "Muhammad, you have fallen down (Üftade) from your high dignity you owned". Since then, Üftade left his occupation as muadhin and would rather help his father. He was then known as Üftade.

In his age of $35^{\text {th }}$, Üftade started teaching by giving lectures in mosques, such as Dogan Bey mosque, Namazgah mosque, and several mosques located in Bursa. As an adherent of Bairamiyyah tariqa, hewas the third generation from the founder (piri), Haci Bayram Wali (833/1429). The sufi genealogy he gained was from Hizir Dede as the student and calip of Haci Bayram Wali. And from Üftade, Celvetiyah tariqa was born and derived by Aziz Mahmud Hudayı.

Though the tariqa was more closely related to Aziz Mahmud Hudayı by observers, this tariqa was a spiritual way practiced by Üftade. Nevertheless, few people confirm that the founder of Jalwetiyah tariqa was Üftade. Ismail Hakiki, who was one of the spiritual guides of Jalwetiyah tariqa, opined that this tariqa was still in hilal (a little visible moon) shaped in the period of Ibrahim Zahid al-Jailani. Its true full moon was shaped in the period of Üftade, and completely a moon shape in the period of Aziz Hudayı. Thus, Üftade was the prominent figure who established the tariqa (Bursawi 1921, 44).

Some literature note that Üftade raised to become khalifah of the Bairamiyyah tariqa from the alignment of his teacher, Muk'ad Hizir (Bahadıroğlu 2003a, 52). However, it is a bit unreasonable fact. This is because Üftade was still 18 years old 
when his teacher passed away. The age of 18 was still obviously young to preside a tariqa group and there is no tradition of tariqa that khalifah was occupied someone in that age since he has no enough spiritual maturity. In the other hand, all of the researchers are convinced that he was one of the Bairamiyyah tariqa khalifahs. This was contrary from what Üftade said, "I've been with my teacher for 8 years when my teacher was still in life. The khalifah had not been given yet and it had been just given when he passed away" (Hudayı, n.d.).

The quotation above described that he obtained the khalifah after his teacher passed away. While no other notes demonstrated that Üftade obtained spiritual education except from Hizir Dede. As a result, the meaning of "my teacher" in his saying is Hizir Dede. The probability of his spiritual master other than Hizir Dede is difficult to prove. If it was so, the voyage of his mysticism (sulük) was barzahi or uwaish character. It is a mystical tutoring (a sudent-master learning process) which does not meet physically in their real life but through dream or vision (Bursawi 1921).

According to Nihat Azamat, the characteristic of Üftade's sufism is his wara', zuhd and taqwa. Üftade was known as a very careful Sufi in deciding halal and haram thing. In a narrative story, Üftade used to leave halal and subhat (in-between) things, for instance, his rejection of gifts by sultan. One day, Sultan Sulaiman Kanuni-who banned him to quote Ibn 'Arabi's thoughts in his speech-invited him to Istanbul for honoring him as a spiritual guide (murshid) of tariqa. In the meeting, Sulaiman Kanuni intended to give him a tract of land for the elevation of tekke (a tariqa boarding school) Üftade did. But, he refused it. When Sultan knew that Üftade refused the gifts (two tracts of land) for his tekke, he realized that what was stated by his ministers about Üftade being a materialistic spiritual guide was not true (Azamat 2012). 
This courtesy records Üftade's carefulness toward something that he did not gain it by himself except from his exertion. Üftade did not explicitly say that the Sultan's gift is haram. What he did was just for preventing his tekke from shubhat. Another example that shows Üftade's carefulness could be seen from Üftade's decision who left his occupation as a muadhin because he got salary from the government. All of these was done by Üftade in order to avoid something that was not clearly halal.

Üftade's ideas were documented in several masterpieces. There are his three masterpieces documented. Those were Vâkiât, Divan', and Hutbe Mecmuati (collection of Khutbah). From those three masterpieces, only Divan has been published, printed, and translated into France and English. Üftade's masterpiece Vâkıât is still there until now but archived. It can be found in some library archives in Istanbul, Bursa, and Ankara.

Üftade passed away in his 90 . When approaching his, his body was infected by some disease. Realizing that his life was about to end, Üftade called Aziz Mahmud Hudayı and made a wish to begin giving spiritual education in Sivrihisal area. Not long after doing his wish, Üftade passed away. Approximately on Jumadi al-Awwal 12, 988 H./ July 26, 1580 M. Before Üftade passed away, Aziz Hudayı had been in Bursa and got a chance to bury his corpse in a mosque in Hisar (Bahadıroğlu 2003a).

Üftade's struggles in spreading Sufism was then continued by Hudayı who became his khalifah. According to Ismail Hakki Buisavi like what has been quoted by Kara Musthafa, among Üftade's influences in Sufism are two great Ottoman scholars i.e., Aziz Mahmud Hudayı and Kemal Dede. All of them, according to Hakki, are wali kamil. Between those two students, Üftade prefered Hudayl to became his khalifah (Kara 2001, 299).

\footnotetext{
${ }^{4}$ Divan was translated into French by Paul Ballanfat with the title "Hazret-i Pir-i Üftade: Le Divan” in 2001 and published by Les Deux Oceans, Paris. Then in 2005 translated into English by Anqa Publishing under the title "The Nightingale in the Garden of Love".
} 


\section{Vâkiât: Üftade's Masterpiece}

Vâkıât is one of Üftade's masterpieces. ${ }^{5}$ It is a masterpiece that was not written directly by Üftade but by his student, Aziz Mahmud Hudayı (1038/1629). Vâkıât was written on Friday, $1^{\text {st }}$ of Dzulqa'dah 984 after hijrah/20 $0^{\text {th }}$ of January 1577 M. Its writing began when Aziz Mahmud Hudayı did his Sair al-Sulūk process under Üftade's guidance for three years. At that time, also Aziz Mahmud wrote all of what he heard from his spiritual teacher with enthusiasm. After three months, Aziz Hudayı was taken an oath as khalifah by Üftade and left Bursa city, Vâkıât had been completed. It was on Friday, $9^{\text {th }}$ of Shawwal $987 \mathrm{H} /$ $29^{\text {th }}$ of November $1579 \mathrm{M}$ (Kara 2001).

Even though Vâkiât was written in Arabic, according to Kara, Üftade spoke Turkish as the daily language of Ottoman society. What Üftade delivered was written by Hudayı in Arabic, in order to be used by other Ottoman speakers (Kara 2001). After Hudayı passed away on 1003 A.H/1623 A.D. Vâkıât was translated in Turkish by M. Muizzuddin Celeveti who was a student of Aziz Hudayı.

Vâkıât was the answers to the problems of Sufism addressed by Aziz Mahmud Hudayı to Üftade. In that masterpiece, Üftade interpreted Aziz Hudayı's dreams, and explained certain themes on Sufism, such as vuslat, nuzūl, and ittihäd. To help explain those problems, Üftade enclosed Sufis biographies in the first and middle period, their poems, and their ideas. Through this work, it appears that Üftade was eager to enlighten Aziz Hudayı on mysticial terminologies through previous Sufis lives.

Among the Sufis in the first and middle period mentioned by Üftade in Vâkıât are Abu Yazid al-Busțami (874 M), Hallāj al-

\footnotetext{
${ }^{5}$ Basically, the book written by Aziz Mahmud Hudayı is not written by the name Vâkiât. The actual title of this work is "Kalimatun 'Áliyatun Järiyatun baina Hazrat al-Shaikh wa baina al-Fāqir fi Asnai al-Suluk". But later the readers were more familiar with the name Vakıât-ı Üftâde. To find out more about Vâkıât, see Mustafa Bahadıroğlu (2003b).
} 
Manșūr (922 M), Al-Ghazali (1111 M), Haci Baktas Wali (1271 M), Muhyiddin Ibn 'Arabi (1240 M), Sadreddin Konawi (1274 M), Sems At-Tibrizi (1248 M), Jalāluddīn al-Rūmi (1273 M), and Nasiruddin Hoca $(1284 \mathrm{M})$. There are also other figures non-sufism circle, such as Abu Hanifah, Abu Yusuf, Ibn Sina, Fahruddin Rozi, and some names of the Ottoman kings, like Yawuz Sultan Salim (Hudayı, n.d., 16).

Although mentioning some Sufis biographies, Vâkıât was not a historical masterpiece. Such mentioning is aimed only at giving introduction for Aziz Hudayı about mysticism terminologies with the approach of figure studies.

From those figures, the names frequently mentioned are Ibn 'Arabi, Yazid al-Busțami and Jalāluddīn Rumi. Ibn 'Arabi is mentioned almost in every part of Vâkıât volume. Üftade quoted his opinions. Ibn 'Arabi's name was mentioned around 40 times. Jalāluddīn Rumi was mentioned 20 times. Moreover, Üftade quoted their work quite frequently, such as Fuṣuṣ al-Hikam, Futūhāt al-Makkiyyah, and Masnawi.

As a Sufi who was born and lived in the transition era of Seljuk empire to Ottoman empire, Üftade provided new facts about the dynamics of tariqas that emerged and developed in the first time of Ottoman Empire, such as Bayramiyah and Melamiyah. The fact delivered by him is very authentic. Üftade told enough new material for Sufism historians and scholars who are concerned with Sufi groups and Islamic Studies in the early Ottoman period.

\section{Ibn 'Arabi in Üftade’s Views}

Ibn 'Arabi's name is mentioned frequently by Üftade in Vâkıât. His discussion on Ibn 'Arabi can be divided into some theme; Üftade's views on Ibn 'Arabi's thoughts; Üftade's meeting with Ibn 'Arabi in his dreams; Üftade's analysis toward Ibn 'Arabi's opuses; History of Ibn 'Arabi's grave. 
Reading Vâkiât is like reading an introduction for understanding Ibn 'Arabi's thoughts. Almost in every discussion, Üftade always emphasizes his argumentations on Ibn 'Arabi's thoughts. From this, it is known that Üftade admired Ibn 'Arabi. At least, there are three important indications proving that Üftade was influenced Ibn 'Arabi's thoughts; 1) Üftade's frequent quotes from Ibn 'Arabi's opinions either from Fușuș al-Hikam or Futūhāt al-Makkiyyah; 2) Üftade's declaration on Ibn 'Arabi's name as Shaikh al-Akbar; 3) Üftade's dream and vision several times with Ibn 'Arabi (Hudayı, n.d.).

Üftade's proclamation on Ibn 'Arabi as Shaikh al-Akbar is a way of respect and indicates that Ibn 'Arabi is positioned as the high class Sufi figure. In his opinion, after șahaba (companions of the prophet), there will be four groups of humans who will become khalifah of Allah (rijāl Allāh). One of them are those who get the Shaikh Akbar title (Hudayı, n.d.).

Üftade's numerous citation on Ibn 'Arabi's thoughts proves that he was significantly influenced by Ibn 'Arabi's. In many opportunities, Üftade often used Ibn 'Arabi's theories for answering questions addressed to him. For instance, when he answered Aziz Hudayı's questions, Üftade repeatedly refered to Ibn 'Arabi.

In relation to Ibn Arabi's thought which is deemed contradictory with Islamic law by Hudayi's critics, Üftade gives comments what Ibn 'Arabi wrote does not contradict Islamic law as accused. According to Üftade, common people and scholars just do not have a capability for understanding Ibn 'Arabi's statements. Those who deem that Ibn 'Arabi is wrong are less intellect and have short capability in understanding Ibn 'Arabi so that they cannot see comprehensively Ibn 'Arabi's ideas (Hudayı, n.d.).

Üftade argues that though Sufis reaches a high status of Sufism level, they still must hold onto Islamic law (sharia) for the 
perfection of a $\mathrm{mu}^{\prime} \mathrm{min}$ is measured through their consistence to do sharia. When someone was jadhab, and denies sharia, , it is, in a view of Üftade, a kind of weakness (Hudayı, n.d.).

It can be known from the history of prophets life. None of them experienced losing their mind and became stressful. Furthermore, Üftade proposes that in a perfection of the Sufi level, the mind must be perfect too. Because from the perfection of mind, someone can practice sharia consciously. Those who lose their mind, must neglect and break sharia. How can then they reach tariqa and haqiqa? If they have failed in the first step. Because the way for reaching the complete spiritual level needs healthy mind. It is like a Sufi condition who is in the top level of spirituality. Islam plays an important role in keeping the healthy mind of human (Hudayı, n.d.).

To emphasize his arguments that Ibn 'Arabi is not in contrast with sharia, he told what he understood from Ibn 'Arabi's explanation in his dreams. One day Ibn 'Arabi asked his student "do you ever see my behavior that breaks sharia?" the students answered, "no, we whenever see that". Then Ibn 'Arabi said "alhamdulillah, years you are with me, in spite of it. I'm not with you”. Üftade argues that Ibn 'Arabi was in istighrāq (being immersed in God) in that time, his body is in our world, but his spirit is in the world malaküt (the angelic world). Even so, Ibn 'Arabi never showed doing or saying which breaks sharia since sharia and tariqa are the way to reach ma'rifa and haqiqa. How can someone reach haqiqa if his syaria is not complete? If anyone doesn't do sharia and tariqa, they will not reach the ma'rifa and haqiqa level (Hudayı, n.d.).

According to Üftade, Al-Hallāj was the opposite of Ibn 'Arabi. The ability which Ibn 'Arabi had does not belong to Al-Hallāj. When Hallāj al-Manșūr said "anā al-haqq", it is a form of weakness possessed by him. He was shaken by a little of water that 
comes from the sea of malaküt, while he was unable to control himself, the expression "anā al-haqq" came out of his mouth. In commenting on what was experienced by al-Hallāj, Üftade is in line with as-Sibli's comment. According to al-Shibli, though expression ana al-haqq is haqīqa language and can be explained, his expression and situation were in a fatwa (sharia) zone. So, for avoiding denigration among Sufis and lay people, Al-Hallāj must be punished (Hudayı, n.d.). From this, it is known that even though Ibn 'Arabi was at a high level status of Sufi, he was still consistent to hold unto sharia. It was different from other Sufis who are not able to control themselves so that they speak shatahat ${ }^{6}$ like what happened in al-Hallāj case.

Then, Üftade told that when Ibn 'Arabi was in Marocco he reached the highest level in Sufism, being quț al-aqtāab. Not all of wäli could reach this level. This was signed by Ibn 'Arabi's recitation (wird), which was a recitation of great holy person (wāli). This recitation was " $y \bar{a} H u$ ", $y \bar{a}$ men Hu"," $y \bar{a}$ men la ilāha illa $H u$ ". "Hu" is the name of which indicates his Absolute Substance. It is a short recitation, but aims directly to address his fana'. Especially in Üftade's opinion, Ibn 'Arabi passed qut b $a l$-aqtāab level, and succeeded in passing "seventy levels", based on Üftade's term. Because Üftade saw that Ibn 'Arabi was in a lot of sulūk levels which he called "Fana' al-Sharîf", passed a world of mulk and malakūt, a condition in which Allah swt. is the only one he saw, no other beings (Hudayı, n.d.).

In the context of $w \bar{a} l i$ aqtāa $b$ level, Üftade saw that there were two qutb al-aqtāb who were the leaders of wāli, God's saints. One of both was in the world of mulk ('alam al-mulk), while the other was in the world of malakut. In its service role, both

${ }^{6}$ Statement of Sufis which cannot be understood by lay people since they are in the state of fana' (annihilation) and they cannot control it. 
of area helped one each other. Meanwhile, the one who had $q u t b$ al-aqtāb level absolutely was prophet Muhammad saw. It means that among prophets and wāli in the earth, qutb al-aqtāb was prophet Muhammad saw. Because prophet Muhammad saw. was qutb al-aqtāb in the world of mulk and malaküt. Like prophet Muhammad saw., Üftade placed Ibn 'Arabi as another figure who became qutb al-aqtāab in the world of mulk and malakūt.

Related to those who can become quṭb al-aqtāb in Üftade's era, he insisted many times that qutb al-aqtāab was out of common people views. It means that no one knows who is qutb $a l$-aqtāa his era. For example, Üftade maintained that most of the external or physical appearances of Wāli Allāh are bad, because they want to cover themselves from human beings. In Ibn 'Arabi's era, Ibrahim al-Hanadi was a qutb, but his appearance showed that he was not a guardian (wāli). Ibn "Arabi said to him "I know who you are" and Ibrahim answered. "This is secret, don't be careless, my brother" (Hudayı, n.d.).

In another history, When Ibn 'Arabi was in Marocco, he gathered with a group of mystical persons (Sufis), they were seven people and one of them was their leader. One day Ibn 'Arabi told them "Everything is opened for me in this world, so that I can see everything". One of them asked, "Who is the qutb alaqtāb in this era?" Ibn "Arabi answered "He is among us", the one who questioned it understood and got the answer for his question.

According to Ignaz Goldzeher, there were ten levels of wāli in mysticism, among them is qutb al-aqtāab, then his two assistants, imām yamīn and imām yasār, four autad or umūd, seven $a f r a \bar{a}$, then $a b d \bar{a} l$, sixty nuceba', three hundred nuqaba', five hundred $a s \bar{a} i b$, then hukema $\bar{a}$ ' or mufredun and the last is rejabiyyun. From those levels, the meaning of seven groups of Sufi 
was seven afrad (Goldziher 1988, 3-4). According to Üftade, Ibrahim al-Hanadi was the leader of those seven holy persons.

Narration above, according to Üftade, explained that knowledge of guardian (wāli) was specialized in mysticism, so that not every man could see and know it. A knowledge about a person's status as wäli is secret among holy persons. Common people do not have an ability to recognize them and realize their characteristics. This ability is only for special people who have passed diverse spiritual levels of wāli. Meanwhile, Ibn 'Arabi's knowledge about Ibrahim al-Hanadi was a proof that Ibn 'Arabi's level was very high so that he had an ability to know the saint level of spirituality .

\section{Üftade's Meeting with Ibn 'Arabi}

In Vâkıât, Üftade narrated that he met Ibn 'Arabi in his dream for many times. For example, when he made a decision that Ibn 'Arabi was a mystical person (Sufi) who had the highest level. This statement was an analysis based on his meeting with Ibn 'Arabi in his dream. To state that Ibn 'Arabi was a great Sufi who had a high level, Üftade compared between Ibn 'Arabi and two great and popular Sufis, they were Yazid al-Bustami and Al-Ghazali. Üftade told his meeting with Ibn 'Arabi to Aziz Mustafa Hudayı, in the following:

"In my dream, I met Ibn 'Arabi and talked with him, he said to me, one day, I asked Allah about Yazid al-Bustami. Allah swt. answered "I accept Yazid al-Bustami, I love him and I love his lover." Then, I wrote a biography of Yazid al- Busțami. In this process, I saw that Yazid al-Bustami stated, "I saw all of the creatures were dead, then I prayed for their corpses with four-time takbir." According to Ibn 'Arabi, correcting Yazid's statement, He (Yazid) should not say that, he should say, my desire is dead and I pray for my self. Because a perfect mystical person do not see other people faults. But he only see his own fault. A Sufi 
was prohibited from being busy with another thing. Then I (Üftade) asked, you are not only busy with yourself but also with Yazid's fault. Unfortunately, Ibn 'Arabi didn't answer" (Hudayı, n.d.).

From Üftade's story above, there are some acceptable messages, among them is about irshäd (giving direction) in mysticism. There are some Sufi who have the ability to give irshäd, (like Ibn 'Arabi), and some do not (like Yazid al-Busțami). The second group is a number of Sufis who only reached a high level-by arguing that Allah swt. loves Yazid and his lover-but were not murshids (spiritual guides). In another term, those who were concerned with it do not have the ability to give irshäd in the haqiqa level.

Üftade agreed that Yazid al-Busțami is one of a great Sufi who obtained the level of wushul (being halted) at Allah swt. It is based on the book Nefehat al-Uns that belongs to Molla Abdurrahman Cami. Nevertheless, he is still convinced that Yazid al-Bustami is not a Sufi who are commanded to be a spiritual guide (murshid) and has the capability to give irshäd.

In the other side, Üftade said that Ibn 'Arabi seems to humiliate Yazid al-Busțami for Ibn 'Arabi was in tanazzul, not in wushlāt. Due to Üftade's opinion that there are two nazars (conception); vuslät nazar and tanazzul nazar. The first means that the subject sees something from the area of truth (haqiqa). By this seeing, all of the things seen by the subject is a goodness. The second sees a problem from the area of sharia and tariqa in which the subject may differentiate between right and wrong, goodness and badness. Based on this theory, Üftade said that Ibn 'Arabi sees Yazid al-Bustami from the perspective of sharia and tariqa. Therefore, Ibn 'Arabi saw Yazid al- Busțami's lack.

Üftade considered that story of his conversation with Ibn 'Arabi happened twenty years ago. It is when he was in a state 
of lay person and imperfect spiritually, until he was questioning what Ibn 'Arabi's view on Yazid al-Busțami. He then apologized to Ibn 'Arabi as his respect and his confession of mistake, and kissed Ibn 'Arabi's long flowing robe (Hudayı, n.d.).

Üftade said simply that qutb al-aqtāb is a personality that has achieved vuslāt and tanazzul. It means that quṭb al-aqtāab seen from many sides, which are sharia, tariqa, haqiqa. Ma'ri$f a$ (being in the level of haqiqa) is the most perfect personality. By the other term, they are individuals arriving the four levels. Propeth and the specialists (ablu) of irsyad are individuals who have arrived at vuslāt and tenezzul. For example, Prophet Muhammad saw. when he commanded Bilal "arihnā yā Bilāl" or ordered Aisyah "Aisyah, let's have a conversation". All of it happened when he was in tanazzul. Nevertheless, a Sufi could not see badness and lackness in everything he saw when he is in vusül. Nonetheless, when he is in tanazzul, he can see badness and goodness and can remind their wrongness and guide them to the right way. Until when the messengers and the specialists of irshäd saw truly (haqiqa), they could see only the goodness, nothing is negative, even though it was a dirty thing. But, if they saw with sharia and tariqa, they would differentiate between halal and haram, goodness and badness, etc. In this state, they are obliged to give irsyad.

Üftade returned to compare Sufis coming from Andalusia with Al-Ghazali to affirm his opinion about Ibn 'Arabi's high status. This comparison does not mean to make preference of a Sufi to others. It is just to know their own characteristics. According to Üftade, al-Ghazali is a great Sufi scholar, he spent twelve years observing a Sufism way (sulük). Unfortunately, according to him, he cannot succeed in getting one of tajaliyyāt states; tajaliyyāt al-af'âl, al-șifat and al-dhāt. It is because his knowledge prevented him to reach haqiqa. In the mean time, Ibn 
'Arabi was a Sufi who reached haqiqa level. He was one of the perfect Sufis and Sufi scholars certainly higher than Al-Ghazali. Üftade saw that Al-Ghazali's great masterpiece, Ihya Ulum al-Dīn, is the most important masterpiece in Islamic literature. Nevertheless, his level is not higher than Ibn 'Arabi's level (Hudayı, n.d.).

In Vâkiât, several moments of Ibn 'Arabi's life are mentioned. There are three topics; (1) khalwat which was done by him, (2) his khalifah, and (3) advice given to him. Üftade told that Ibn 'Arabi was in khalwat (a spiritual seclusion) for many times in a mountain located in Lebanon in forty days. (Huday1, n.d.). He said that khalwat in sufism theory is a primary need for sālik and is an effort that has to be done by sälik for cleaning themselves from everything that prevents them to be close to Allah. This method might be done by being separated physically with society. In the Otoman Sufi tradition, there are two terms, first is named khalwat and the second is jalwet. Both terms were adopted to be the names of tariqa in the Ottoman era and become their own characteristics.

In Naqshabandiyah's tradition, jalwet means khalwat. They call it by "halvet der encumen" (khalwat in among society). Furthermore, this concept was also adopted by Üftade for his behavior. Because of that, his tariqa was called Jalwetiyah. The characteristic of Jalwetiyah in giving priority to jalwet than khalwat is an evidence that there is a relation between Jalwetiyah and Naqshabandiyah. Their genealogy is united at Haci Bayram Wali, the founder of Bairamiyyah tariqa (Yilmaz 1982, 241).

Returning to Ibn 'Arabi, Üftade said, after Ibn 'Arabi finished from his khalwat, he was able to get a new higher level. This is Ibn 'Arabi's speech quoted by Üftade;

"After my teacher passed away, to listen to the perfect Dhat, first I took a bath to clean myself, washed my cloth 
then I wore it. Then what I caught inside my self, I was in front of a door when I got in. This is how I got this position. For me, everything I get is considered as my teacher" (Hudayı, n.d.).

Accordingly, Üftade explains about how the process of a $s \bar{a}$ lik (a student in a spiritual way) is able to obtain khalifah task from his spiritual teacher (murshid). According to him, this $\mathrm{kh}$ ilfah task is something which is not able to be looked for and can not be refused when it's given. That is the same as what he learned from Ibn 'Arabi's story.

"Ibn 'Arabi , in a couple times, receive a task from his teacher to be 'khalifah', but he still stands receive that task. Finally, his teacher expel him from his residence. Then he went to leave his teacher's residence to another district. Until on a certain day he stops in a city, it was being a tradition there that the king would serve all guest who came to that city by inviting them to a dinner, and he was also invited. It appeared that he was not the only guest but two others were also invited by the king. After enjoying the meal they slayed in the castle. Unfortunately, in the middle night, the two others left him there. In the next morning, the king had already lost his bag full filled with gold. Hearing that, surely the king sent his soldiers immediately to bring all the guest inside the castle, included him. Knowing that, he provided for his self I'm not the thief", Then the king commanded his soldiers to tie and hang him. In the form to avoid that, he should "Yes, I stole it". Suddenly, the other two guests came and should "release him, he was not the thief, we are". Then the king was questioning about his inconsistency his answer. Then he explained, that this was caused because he refused $\mathrm{kh}$ ilfah task from his spiritual teacher. Knowing that he is a great Shaikh, the king sniffed at his hand and became his student" (Hudayı, n.d.). 
Üftade states that what happened on Ibn 'Arabi is the result of his refusal. He also states that Ibn 'Arabi's intention to refuse that task was not because he do not obey his teacher, but it was because he felt he did not deserve when Ibn 'Arabi was being accused as thief. Üftade further commented that Ibn 'Arabi started to be aware that it was because he refused the task. His awareness leads Ibn 'Arabi to say: "Yes, I'm now ready to become khalifah of my teacher". From his saying also, the help comes that the true thief admited that he is the thief.

According to Üftade, the philosophy of this event in mysticism is that khalifah is something can not be hoped and waited for it is not the purpose of Sufism and all of the sufis are not deemed to be khalifah. Khalifah is a position given by Allah swt. with his authority to Sufi by the spiritual teacher. Once, the kholifah task has already been given by the spiritual teacher it can not be refused. Its refusal is as same as refusal to what Allah has commanded (Hudayı, n.d.).

In terms of giving the spiritual guidance, Üftade believed that there was a good commandment that guide him to Andalu (Ottoman Asia's side) and he commanded (demanded) himself "there, (in Andalu) will be a man who is ready to obtain/learn with you, go! and guide him!". Ibn 'Arabi went to Konya and met with a young man named Sadruddin Konawi. Ibn 'Arabi married his mother, a widow. Then Sadruddin Konawi went to Mecca to continue his spiritual education for Ibn 'Arabi's command and returned after to Konya to be khalifah of Ibn 'Arabi (Hudayı, n.d.).

Roughly speaking, According to Üftade statement, a way of Sufi is not a way based someone will. The way they do is the way based on and by Allah's will either by spiritual teachers or by his heart. What they see by eyes, hear by ears, touch by hands and walk by legs is Allah swt. Because of that, in a very mystical tradition, it is prohibited to be asked about "what? and why?" 


\section{Üftade's Analysis of Ibn 'Arabi’s Work}

Like other mystical Suffi who give their comments on Ibn 'Arabi's work. Üftade also in Vâkiât comments on his works, either Futūhāt al-Makkiyyah or Fușuṣ al-Hikam. In Üftade's opinion, both are manuscripts based by a divine inspiration "in the writing of Futūhāt al-Makkiyyah book, none interrupts Ibn 'Arabi, even himself". The statement means that what let he write was not based on his mind or his desire, his position as the author is nothing except a translator of the interpreter from what Allah has given through the prophet Muhammad in a dream.

Ibn 'Arabi said something the same (like that) at the beginning of his own book (Fusus al-Hikam). This is the story that shows he met Nabi Muhammad. in $627 \mathrm{H} / 1230 \mathrm{M}$. In that meeting the prophet had given him a book and commanded him to explain it to lay people (Afifuddin 2015, 35). Because of this, Üftade agrees with Ibn 'Arabi about what was written at the beginning of Fușus al-Hikam that he is nothing unless he just translated the manuscript by the divine inspiration into his own language.

In Üftade's point of view, the work of Fușuṣ al-Hikam was purposed to avoid any deviant way, it could be conclude/taken by the note in Vâkiât in the following:

"There were two learned people in the Ajam territory, both lived in the basement. They decorated that room with a beautiful view within 12 years both of them busied themselves with 'ilm (knowledge). But as long as the progress of deepening of knowledge, they had never seen the beautiful view inside the room for getting ma'rifa. They preferred to be poor than rich, with all of that, they both got a good reputation in front of shaking. It was known that the two Sufi were studying Fușuṣ al-Hikam created by Ibn 'Arabi. They found and understood that Fușuṣ al-Hikam had no controversy with Islamic religion 
then the news of prohibiting of reading Fușuṣ by amoung of scholars of Islam was heard by the great hakim. Efficiently, the great hakim assembled all of the scholars of Islam including the two Sufi living in the basement. In front of the great hākim and other scholars, they could explain contents of Fușus al-Hikam, then the great häkim allowed the reading of Fușuṣ al-Hikam"(Hudayı, n.d.).

According to Üftade's perspective. Fușuṣ is a comprehensive work. This small work even (in his opinion) can give answers to every doubt of beliefs. Unfortunately, the scholars of Islam in the era of Ibn 'Arabi seems more prior. Before doing study toward what was written by Ibn 'Arabi, especially Al-Hikam, they refused it beforehand (Hudayı, n.d.).

\section{History of the Existence of Ibn 'Arabi's Grave}

The history of Ibn 'Arabi's grave is as important as the three themes discussed before. In Vâkıât, there are some narratives telling about the Ibn 'Arabi's grave. According to Üftade, Ibn 'Arabi passed away in Damascus on $12^{\text {th }}$ of Rabī' al-Akhīr 638 $\mathrm{H} / 10^{\text {th }}$ of November 1240 . He was buried in Ibn Zeki family's grave located in Kasiun Mountain, the district of Salihiye which is also the same place where two sons of Ibn 'Arabi were buried. It had been destroyed by a group of anti-sufism. Afterwards, Ibn 'Arabi's grave was found again and taken care by Yawus Sultan Salim's government. In that time, the sultan was on a trip going back from Egypt expedition, he then stopped in Syam. In his transit, Sultan commanded his army to ensure the existence of Ibn 'Arabi's grave. When it was found, a mosque and his tekke (a tariqa boarding school) were built beside it. Up to now, Ibn 'Arabi's grave is always visited by people from everywhere.

Through Vâkiât, Üftade said that there are two histories about the invasion of Ibn 'Arabi's grave. The first history tells that Yavus Sultan Salim dreamed and met Ibn 'Arabi. The second 
history, Ibn 'Arabi's grave was found by Ottoman army forces after the conquest of Damascus. About the first history, Yavus Sultan Salim in one day came to his spiritual teacher named Halimi Celebi (922/1516). He told him that he dreamed of coming to Arab territory and met scholars leaders there. But, in the dream, all of the scholars he met refused to give Arab territory to Sultan Salim except Ibn 'Arabi, because of Ibn 'Arabi's permission, every scholar who disagreed before, finally followed what was permitted by Ibn 'Arabi. In interpreting the dream of Sultan Salim, Halimi Celebi said "In the future, you will be able to conquer Arab. Find and build Ibn 'Arabi's grave!'. Sultan Salim was then successful to do his teachers' command. That means to find and build Ibn 'Arabi's grave.

The second history of the discovery of Ibn 'Arabi's grave was narrated by Üftade from his teacher Hizir Mukad Dede. In his opinion, after the conquest of Syam, Sultan Salim assembled the surrounding societies in the building. The building was formerly a church in the Salihiye district, it was cleaned. In the progress of cleaning, they found the grave written "Muhammad ibn Ali" on the gravestone. A mosque and tekke were built on it afterward (Hudayı, n.d.).

Whether the first or the second history on the Ibn Arabi's grave is alike. They inform that the discovery of Ibn 'Arabi's grave is a command of Yawus Sultan Salim. The difference between both histories is only the first history is preceded by a dream. Meanwhile, mosque building tradition near from grave is Ottoman king habits. This kind of habits can be found in Turkey's territory today.

\section{Conclusion}

From the explanation above, there is something to conclude. First, in Üftade's perspective, Ibn 'Arabi is a great Sufi, who possesses a high level of Sufi. In sufism, his level in status as a schol- 
ar is kutubul aktab, the highest level of status as a scholar. A $q u t b$ al-aqtāab, according to Üftade, is a leader of scholars in the world of mutlaq and malakut.

Second, if he is compared to another big Sufi, his position is above Yazid al-Busțami, Al-Ghazali, and Al-Hallāj. The difference between Ibn 'Arabi and Yazid, according to Üftade, is on the authority of showing guidance. Although Yazid had experienced vusul, he is not a scholar who has the ability to give guidance (irshäd). Meanwhile, if Ibn 'Arabi is compared to Al-Ghazali, he is still above Al-Ghazali. Although Üftade believes that Al-Ghazali's works are the most authoritative in sufism, it doesn't make him higher than Ibn 'Arabi.

Third, according to Üftade, the accusation of Muslim scholars of religion which disagrees with Ibn 'Arabi's opinion cannot be corrected because Ibn 'Arabi is a Sufi who has passed every level of the journey that should be assailed by a salik, from sharia, tariqa, and haqīa. Ibn 'Arabi's level of haqīqa has never made him in contradiction with sharia like what happened to Al-Hallāj. And fourth, based on the history by Üftade, Ibn 'Arabi passed away and was buried in Damascus, meanwhile, his grave was found because of Yavus Sultan Salim's command when he conquered Damascus.

\section{Bibliography}

Afifuddin, Sulaiman. 2015. Sharh Fuṣuṣ Al-Hikam li Al-Shaikh Al-Akbar Ibn 'Arabi. Beirut: Dār al-Kutūb al-'Ilmiyyah.

Azamat, Nihat. 2012. Üftade Dalam Din Islam Ansiklopedisi. Ansikloped. Istanbul: Isam.

Bahadıroğlu, Mustafa. 2003a. Üftâde Dîvânı. Bursa: Hz. Üftâde Yayınları.

. 2003b. "Vâkıât-1 Hüdâyî’nin Tahlîl ve Tahkîki.” Uludağ Universitesi Sosyal Bilimler Enstitüsü. 
Bursawi, Ismail Hakki. 1921. Silsile-i Celvetiyye. Istanbul: Pamuk.

Goldziher, Ignaz. 1988. Ebdâl. C. IV. Istanbul: İA.

Hudaverdi, Adam. 2005. "The Relationship Between Muhyiddin Ibn Arabi And Sadreddin Al-Konevi." Journal of Academic Studies 6 (24).

Hudayı, Aziz Mahmud. n.d. "Vakiat I-II.” Haci Seliağa Ktp. Hudayı Kit., 250.

. n.d. "Vakiat I-III." Haci Seliağa Ktp. Hudayı Kit, 249.

Kara, Mustafa. 2001. Bursa'da Tarikatlar ve Tekkeler. Istanbul: Sir Yayıncilik.

Kilic, M. Erol. 2013. Mubyiddin Ibnu Arabi Dalam Din Islam Ansiklopedisi. Istanbul: ISAM.

Yilmaz, Hasan Kamil. 1982. Aziz Muhammad Hudayı ve Celevetiye Tarikate. Istanbul: Erkam Yayınları. 